\title{
Biological Control of Gray Mold with Ulocladium atrum in Annual Strawberry Crops
}

P. Boff and J. Köhl, Plant Research International B.V., P.O. Box 16, 6700 AA Wageningen, the Netherlands; M. Jansen, Fruit Research Station, P.O. Box 200, 6670 AE Zetten, the Netherlands; P. J. F. M. Horsten, C. Lombaers-van der Plas, and M. Gerlagh, Plant Research International B.V., Wageningen, the Netherlands

\begin{abstract}
Boff, P., Köhl, J., Jansen, M., Horsten, P. J. F. M., Lombaers-van der Plas, C., and Gerlagh, M. 2002. Biological control of gray mold with Ulocladium atrum in annual strawberry crops. Plant Dis. $86: 220-224$.

The efficacy of the fungal antagonist Ulocladium atrum to control gray mold in annual strawberry crops using waiting-bed transplants under field conditions was investigated. Seven field experiments were conducted with strawberry cv. Elsanta during the summer seasons of 1996-99 in the Netherlands. Treatments included untreated controls, fungicide programs, $U$. atrum spray programs, and crop sanitation. Under low disease pressure, $U$. atrum spray programs effectively reduced gray mold at harvest in four of seven experiments. Sprays of $U$. atrum starting at transplanting resulted in better control of gray mold than sprays starting at the beginning of flowering in only one of five experiments. Removal of necrotic leaves did not affect the level of gray mold, which demonstrated that strawberry leaves were not a significant inoculum source for Botrytis cinerea in this annual cropping system. These results suggest that $U$. atrum can be effective in reducing gray mold in strawberry crops, and further studies on the use of the antagonist in annual systems should consider flowering time as the best period to apply this antagonist.
\end{abstract}

Additional keywords: antagonism, Botrytis cinerea, Fragaria $\times$ ananassa

Gray mold of strawberry (Fragaria $\times$ ananassa Duchesne) incited by Botrytis cinerea Pers.:Fr. can cause severe yield losses in any of the strawberry cropping systems used worldwide (15). The nonspecialized necrotrophic fungus $B$. cinerea can multiply on debris of a broad range of plant species $(1,7)$ and disseminate as conidia. Senescent flower parts appear to facilitate the infection of $B$. cinerea on developing fruit, leading to fruit rot (7).

In the Netherlands, the majority of strawberry field crops are grown using the so-called waiting-bed transplant system

Corresponding authors: P. Boff and J. Köhl

E-mail: pboff@epagri.rct-sc.br and

j.kohl@plant.wag-uv.nl

Permanent address of P. Boff: Agricultural Research and Rural Extension Agency of Santa Catarina State (EPAGRI), P.O. Box 502, CEP 88034901, Florianópolis, SC, Brasil.

Funding for this research was partly provided by the Brazilian Government-Coordenação de Aperfeiçoamento de Pessoal de Nível Superior (CAPES; Proc. 2959/95-0), which included a full scholarship to P. Boff. We also acknowledge the European Commission (BIOSPORSUPPRESS; FAIR3 CT96-1898) for partial financial support of the research.

Accepted for publication 8 October 2001.

Publication no. D-2002-0114-04R

(C) 2002 The American Phytopathological Society
(18). This cropping system is also adopted in other northwestern European countries. In such a system, the transplants are produced in waiting beds from August until December and stored at $-2^{\circ} \mathrm{C}$ until transplanting in the following spring or summer (18). Advantages of this system are (i) no plant losses during winter, (ii) flexible planting schedule resulting in harvest periods with higher expected product prices, (iii) lower risk of build-up of populations of soilborne pathogens because of the reduced cropping period, and (iv) better stand quality by selecting transplants that developed a strong multicrown during the waiting-bed time.

Necrotic tissue in the strawberry canopy has been found to be the major inoculum source of $B$. cinerea in perennial strawberry fields (4). The relationships among necrotic tissue present in the crop, flower infection, and subsequent fruit rot have already been documented in that system $(4,8)$. Under Florida conditions, leaf sanitation of strawberry plants conducted in raised beds reduced Botrytis fruit rot but did not increase marketable yield (16). However, the epidemiology in annual strawberry crops using waitingbed transplants and perennial crops may be different. It seems that the amount of necrotic tissue varies with the quality of the transplants and such necrotic tissue does not determine the inoculum pressure of $B$. cinerea for flower colonization and the rate of gray mold development on fruits (3).

Biological control of strawberry gray mold can be achieved by interfering with the infection process of the pathogen at the blossom stage and during development of fruit (2) or after harvest by using yeasts as antagonists (14). Another approach, which consists of suppression of $B$. cinerea inoculum production by Gliocladium roseum, was reported by Peng and Sutton (17). Using a similar approach, Jordan and Pappas (9) suggested suppression of inoculum production by chemical means. In perennial systems, control of strawberry gray mold by reducing initial inoculum production on necrotic leaves within the crop is possible, because infection of most strawberry flowers takes place in a single infection cycle by conidia produced on necrotic leaves present in the crop during flowering (20). This source of inoculum may play a different role in annual cropping systems; therefore, biological control strategies may need to be adjusted accordingly.

A strong fungal competitor in necrotic tissue, Ulocladium atrum was found in bioassays to more effectively exclude $B$. cinerea from dead lily leaves than other antagonists, such as $G$. catenulatum, Aureobasidium pullulans, or Chaetomium globosum (12). For several other crops, such as cyclamen (11), tomato (6), and grapevine (19), it was demonstrated that $U$. atrum can successfully compete with $B$. cinerea, resulting in effective disease control. The effectiveness of a competitive biological control agent applied in an inundative release depends on inoculum density, frequency of application, and the application technique, as well as microclimatic conditions (5). The effect of inundative release of $U$. atrum on gray mold of strawberry has not been tested under field conditions.

The objective of our study was to evaluate, under field conditions, the effectiveness of $U$. atrum in reducing strawberry fruit rot caused by $B$. cinerea in annual strawberry crops with waiting-bed transplants. Attempts were made to optimize timing, initial applications, spraying frequency, and suspension concentration.

\section{MATERIALS AND METHODS}

Experimental plot layout. Seven field experiments were conducted with annual 
strawberry (cv. Elsanta) crops, using waiting-bed transplants cold-stored at $-2{ }^{\circ} \mathrm{C}$ until the day before planting. All experiments were carried out in a randomized complete block design with four to six replications (Table 1). Each plot in experiments 1 and 4 consisted of four single rows of 10 plants per row, with three plants per meter of row length and $0.8 \mathrm{~m}$ between rows. Plots were established inside a field of red cabbage serving as a buffer crop with a distance of $10 \mathrm{~m}$ between plots. Each plot in experiments 2, 3, 5, 6, and 7 consisted of 78 plants in three twin rows of 2 by 13 plants per twin row. The distance between twin rows was $1 \mathrm{~m}$ and within twin rows was $0.5 \mathrm{~m}$, with three plants per meter of row length. The plots were established within a grass field, separated by $10 \mathrm{~m}$ of grass buffer.

Fungal inoculum. Conidial suspensions of $U$. atrum, isolate 385 , were prepared from 4-week-old cultures of the antagonist grown on oat grains (11). Conidia were washed from the substrate in a nylon bag using a camping washing machine (Nova MW 100; Nova, Maastricht, the Netherlands) filled with water containing $0.01 \%$ (vol/vol) Tween 80 . The resulting suspension was filtered through nylon gauze (200- $\mu \mathrm{m}$ mesh). The concentration was determined using a haemocytometer and the suspension was adjusted to the appropriate concentration for each treatment. Suspensions were stored at $4^{\circ} \mathrm{C}$ until use, which took place within 24 or $48 \mathrm{~h}$ after preparation of the suspension in experiments at Wageningen and Breda, respectively.

Treatments. The control treatment was an unsprayed plot except in experiment 1, where water containing Tween-80 at $0.01 \%$ ( vol/vol) was applied weekly from transplanting until fruit began to turn red. $U$. atrum was applied at a concentration of $2 \times 10^{6}$ conidia/ml, except for experiment 7 , in which the concentration was $0.5 \times 10^{6}$ conidia/ml. Application of $U$. atrum began at transplanting (U. atrum transplanting) or at opening of the first flower ( $U$. atrum flowering) and ended when the first fruit turned red. The frequency in application of $U$. atrum varied from weekly to twice weekly, depending on the experiment. Comparative fungicide programs started at first open flower and continued until the first fruit turned red, with application frequencies varying among experiments. Materials used included iprodione (Rovral
WP; Rohm and Haas, France), tolylfluanide (Euparene M; Bayer, the Netherlands), pyrazophos (Curamil; AgrEvo, the Netherlands), thiram (TMTD; Satec, Germany), and pyrimethanil (Scala; AgrEvo). Crop sanitation treatments were carried out in experiments 5 and 6 , and consisted of removal of all senescing leaflets from the strawberry plants twice per week, starting immediately after transplanting until the first fruit turned red.

For experiments 1 and 4, conducted at Breda, U. atrum and fungicides were applied with a knapsack sprayer using a hollow-cone nozzle and air pressure at 200 $\mathrm{kPa}$ at a rate of 500 liters/ha. For experiments 2, 3, 5, 6, and 7, conducted at Wageningen, U. atrum and fungicides were applied with a propane gas-driven knapsack sprayer at $250 \mathrm{kPa}$ at a rate of 750 liters/ha.

Crop management and cultural practices. In all experiments, overhead irrigation was applied during periods of hot, dry weather in order to promote development of $B$. cinerea. Weeding was done mechanically. The soil was covered with straw from beginning of flowering. No insecticides, herbicides, or other fungicides were applied except for experiment 1 , in which deltametrin was applied three times for thrips control, and experiment 4 , in which transplants were treated with a fungicide (fosetyl-Al plus benomyl) at the time of planting.

Incidence of $\boldsymbol{B}$. cinerea on flowers. In experiments $2,3,5$, and 6 , samples of 20 to 30 flowers, each flower from a different arbitrarily chosen plant, were collected per plot at each of two or three sampling dates. In experiment 7, 50 petals, each petal from a different arbitrarily chosen plant, were collected per plot instead of whole flowers. The flowers or petals were harvested at flower maturity, when the anthers appeared brown and the petals started to fall. Flowers were put into plastic boxes $(22 \mathrm{~cm}$ in length by $14 \mathrm{~cm}$ in width by $5 \mathrm{~cm}$ in height) with wet filter paper on the bottom and incubated at $18^{\circ} \mathrm{C}$ for 14 days in the dark. Petals were incubated under the same conditions in sterile plastic petri dishes (14 $\mathrm{cm}$ in diameter and $2 \mathrm{~cm}$ in height) containing moist filter paper on the bottom. After incubation, the presence of sporulation of $B$. cinerea was assessed on the flower parts (sepals, petals, stamens, and pistils) with a stereomicroscope, at $\times 10$ to $\times 100$ magnification. The incidence of $B$. cinerea sporulation on flowers or petals was calculated per plot.

Harvest and postharvest disease assessments. Fruit were picked twice per week. Ripe, symptomless fruit were harvested first and kept separate from harvested, diseased fruit. Fruit with symptoms also were picked when still in the white stage. Healthy and diseased fruit per plot were weighed and counted.

In experiments $2,3,5,6$, and 7 , the ripe and white diseased fruit were assessed for characteristic symptoms caused by $B$. cinerea, Colletotrichum acutatum, or Zythia fragariae. In experiments 1 and 4, symptoms were classified as those of $B$. cinerea and other diseases without further differentiation. Fruit with nonspecific symptoms were placed without contacting each other into a plastic tray $(50 \mathrm{~cm}$ in length by 30 $\mathrm{cm}$ in width by $7 \mathrm{~cm}$ in height) with wet paper on the bottom. The tray was sealed in a plastic bag and incubated at $20^{\circ} \mathrm{C}$ for 2 days in the dark before symptoms were reassessed. Fruit with characteristic symptoms were then added to the corresponding disease category, and fruit with nonspecific symptoms were classified as "other diseases".

Postharvest fruit rot on a subsample of symptomless fruit was assessed for experiments $1,2,3,5$, and 6 . Twenty arbitrarily chosen fruit per plot were placed in a plastic tray $(50 \mathrm{~cm}$ in length by $30 \mathrm{~cm}$ in width by $7 \mathrm{~cm}$ in height) with wet paper on the bottom without contact among fruit, sealed in a plastic bag, and stored at $4^{\circ} \mathrm{C}$ during 5 days in the dark followed by 3 days of incubation at $20^{\circ} \mathrm{C}$. Fruit then were assessed for gray mold incidence.

Data analysis. The statistical analysis was performed by analysis of variance (ANOVA), followed by least significant difference (LSD) tests using Genstat 5 (ver. 4.1; Numerical Algorithmic Group Inc., Oxford, UK). Because of the low values of gray mold incidence on harvested fruit, this variable was transformed using the arcsin transformation prior to ANOVA.

\section{RESULTS}

Gray mold at harvest. The incidence of gray mold in untreated plots was generally low, from 1.4 to $12.3 \%$ of the total fruit (Tables 2 and 3). The application of $U$. atrum weekly at $2 \times 10^{6}$ conidia/ml from transplanting until the first fruit turned red significantly reduced the percentage of gray mold in comparison with the control

Table 1. Location, crop rotation, and transplanting and harvesting dates for strawberry experiments carried out from 1996 to 1999 in the Netherlands

\begin{tabular}{lllccc}
\hline Experiment no. & Location & Previous crop & Transplanting date & No. of replicates & Harvesting period \\
\hline 1 & Breda & Strawberry & 2 July 1996 & 6 & 29 August to 4 September 1996 \\
2 & Wageningen & Grass & 10 April 1997 & 5 & 16 June to 7 July 1997 \\
3 & Wageningen & Grass & 27 June 1997 & 5 & 11 August to 25 August 1997 \\
4 & Breda & Strawberry & 25 June 1997 & 6 & 14 August to 26 August 1997 \\
5 & Wageningen & Grass & 6 May 1998 & 4 & 2 July to 3 August 1998 \\
6 & Wageningen & Grass & 19 June 1998 & 4 & 13 August to 7 September 1998 \\
7 & Wageningen & Grass & 21 May 1999 & 4 & 15 July to 9 August 1999 \\
\hline
\end{tabular}


Table 2. Effect of applications of conidial suspensions of Ulocladium atrum or fungicide program on the incidence of gray mold on strawberry fruit in 1996 and 1997 in experiments 1 through $4^{\mathrm{w}}$

\begin{tabular}{|c|c|c|c|c|c|c|c|c|c|c|c|c|}
\hline \multirow[b]{2}{*}{ Treatments $^{y}$} & \multicolumn{4}{|c|}{ Disease incidence at harvest (\%) } & \multicolumn{4}{|c|}{ Disease incidence at post-harvest (\%) } & \multicolumn{4}{|c|}{ No. of applications ${ }^{x}$} \\
\hline & 1 & 2 & 3 & 4 & 1 & 2 & 3 & 4 & 1 & 2 & 3 & 4 \\
\hline Untreated control & $12.3 \mathrm{a}$ & $5.4 \mathrm{a}$ & $1.4 \mathrm{a}$ & $8.1 \mathrm{a}$ & $38 \mathrm{a}$ & $16.2 \mathrm{a}$ & $21.2 \mathrm{a}$ & $\ldots$ & 8 & 0 & 0 & $\overline{0}$ \\
\hline U. atrum (transplanting) & $4.8 \mathrm{~b}$ & $2.6 \mathrm{~b}$ & $1.1 \mathrm{a}$ & $4.7 \mathrm{~b}$ & $30 \mathrm{a}$ & $10.3 \mathrm{~b}$ & $17.6 \mathrm{a}$ & $\ldots$ & 8 & 11 & 6 & 6 \\
\hline U. atrum (beginning flowering) & & $3.4 \mathrm{~b}$ & $2.0 \mathrm{a}$ & $7.1 \mathrm{a}$ & & $7.8 \mathrm{~b}$ & $21.2 \mathrm{a}$ & $\ldots$ & $\ldots$ & 5 & 3 & 3 \\
\hline Fungicides weeklyz & $11.5 \mathrm{a}$ & $1.3 \mathrm{c}$ & $1.5 \mathrm{a}$ & $3.9 \mathrm{~b}$ & $37 \mathrm{a}$ & $5.7 \mathrm{~b}$ & $15.8 \mathrm{a}$ & $\ldots$ & 4 & 5 & 3 & 4 \\
\hline
\end{tabular}

${ }^{\text {w }}$ Values in the same column followed by the same letter are not significantly different $(P>0.05)$ based on least significant difference tests.

$\mathrm{x}$ The control for experiment 1 was sprayed with water plus Tween- 80 at $0.01 \%$.

${ }^{y} U$. atrum was applied at weekly intervals, starting at the period indicated, with $2 \times 10^{6}$ conidia/ $\mathrm{ml}$.

${ }^{\mathrm{z}}$ Applied starting at beginning flowering. Experiment 1: iprodione $(0.75 \mathrm{~kg} / \mathrm{ha})$, two applications of tolylfluanide $(0.5 \mathrm{~kg} / \mathrm{ha})$ and pyrazophos $(0.15$ liter/ha) in alternation; experiment 2 : thiram $(2 \mathrm{~kg} / \mathrm{ha})$, three applications of tolylfluanide $(0.75 \mathrm{~kg} / \mathrm{ha})$ and pyrimethanil $(0.8$ liter/ha) in alternation; experiment 3: thiram $(2 \mathrm{~kg} / \mathrm{ha})$, tolylfluanide $(0.75 \mathrm{~kg} / \mathrm{ha})$, and pyrimethanil $(0.8$ liter/ha) in alternation; experiment 4 : two applications of tolylfluanide $(0.75 \mathrm{~kg} / \mathrm{ha})$ and two applications of iprodione $(0.75 \mathrm{~kg} / \mathrm{ha})$ in alternation.

Table 3. Effect of applications of conidial suspensions of Ulocladium atrum or fungicide program on the incidence of gray mold on strawberry fruits in 1998 in experiments 5 and $6^{\mathrm{w}}$

\begin{tabular}{|c|c|c|c|c|c|c|}
\hline \multirow[b]{2}{*}{ Treatments } & \multicolumn{2}{|c|}{ Disease incidence at harvest (\%) } & \multicolumn{2}{|c|}{ Disease incidence at postharvest $(\%)$} & \multicolumn{2}{|c|}{ No. of sprays } \\
\hline & 5 & 6 & 5 & 6 & 5 & 6 \\
\hline Untreated control & $8.3 \mathrm{a}$ & $11.3 \mathrm{ab}$ & $8.8 \mathrm{a}$ & $33.2 \mathrm{a}$ & & \\
\hline U. atrum (transplanting $)^{\mathrm{x}}$ & $5.9 \mathrm{~b}$ & $8.8 \mathrm{~b}$ & $14.9 \mathrm{a}$ & $29.3 \mathrm{a}$ & 12 & 8 \\
\hline U. atrum (beginning flowering) y $^{\mathrm{y}}$ & $5.6 \mathrm{~b}$ & $10.6 \mathrm{~b}$ & $6.9 \mathrm{a}$ & $26.8 \mathrm{a}$ & 6 & 5 \\
\hline Fungicide (beginning flowering) & $3.6 \mathrm{c}$ & $3.0 \mathrm{c}$ & $7.5 \mathrm{a}$ & $19.3 \mathrm{~b}$ & 6 & 5 \\
\hline Crop sanitation (transplanting) & $8.3 \mathrm{a}$ & $13.9 \mathrm{a}$ & $8.8 \mathrm{a}$ & $31.4 \mathrm{a}$ & $\ldots$ & .. \\
\hline
\end{tabular}

${ }^{w}$ Values in the same column followed by the same letter are not significantly different $(P>0.05)$ based on least significant difference tests.

${ }^{\mathrm{x}} U$. atrum was applied weekly from transplanting and twice weekly from first green bud appearance with $2 \times 10^{6}$ conidia per ml.

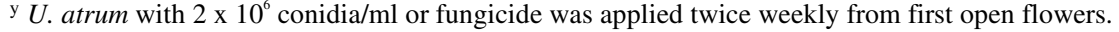

${ }^{z}$ Experiment 5: three applications of tolylfluanide $(0.75 \mathrm{~kg} / \mathrm{ha})$ and three applications of iprodione $(0.75 \mathrm{~kg} / \mathrm{ha})$ in alternation; experiment 6: three applications of tolylfluanide $(0.75 \mathrm{~kg} / \mathrm{ha})$ and two applications of iprodione $(0.75 \mathrm{~kg} / \mathrm{ha})$ in alternation.

in experiments 1,2 , and 4 (Table 2). $U$. atrum, sprayed weekly from transplanting and twice weekly from beginning of flowering, significantly reduced gray mold in comparison with the control in experiment 5 but not in experiment 6 (Table 3). U. atrum applied weekly from the beginning of flowering at $2 \times 10^{6}$ conidia/ml gave significant reduction of gray mold in comparison with the control in experiment 2 but not in experiment 4 (Table 2). U. atrum at $2 \times 10^{6}$ conidia $/ \mathrm{ml}$, applied twice per week from the beginning of flowering, reduced gray mold in comparison with the control in experiment 5 but not in experiment 6 (Table 3). In experiment 7 (data not presented), $U$. atrum applied at $0.5 \times 10^{6}$ conidia $/ \mathrm{ml}$ from the beginning of flowering until the first fruit turned red did not reduce gray mold in comparison with the control when applied at 2- or 4-day intervals. However, the incidence of gray mold in the control treatment $(2.2 \%)$ was low. The effects of applications of $U$. atrum at $2 \times 10^{6}$ conidia $/ \mathrm{ml}$ starting at transplanting were superior to those starting at flowering in only one experiment (experiment 4, Table 2). Fungicide programs reduced gray mold significantly more than $U$. atrum applied at $2 \times$ $10^{6}$ conidia $/ \mathrm{ml}$ from the beginning of flowering in four experiments (experiments 2 and 4, Table 2; experiments 5 and 6, Table 3 ). Crop sanitation by removing senescent and necrotic leaflets did not reduce gray mold in comparison with the control (experiments 5 and 6 , Table 3 ). U. atrum spray programs effectively reduced gray mold in four of seven experiments. In two of seven experiments, at least one $U$. atrum spray program gave the same or better control than the fungicide program (experiments 1 and 4, Table 2). In experiment 3 , the lack of treatment effects can be explained by the extremely low incidence of fruit rot (1.4\% in the control) due to hot, dry conditions.

Postharvest gray mold. Incidence of gray mold in the control treatment after postharvest incubation (8.8 to $38 \%$ ) was higher than at harvest (1.4 to $12 \%$ ) and, in two of five experiments, treatment effects were found (experiments 1 to 3 and 5 to 6 ; Tables 2 and 3). U. atrum spray programs, either from transplanting or from the beginning of flowering, reduced postharvest gray mold in comparison with the control only in one (experiment 2) of five experiments. The fungicide program reduced postharvest gray mold more effectively than the $U$. atrum-spraying program only in one experiment (experiment 6, Table 3). Removal of senescent and necrotic leaflets from strawberry plants (crop sanitation) did not reduce postharvest gray mold in comparison with the control (experiments 5 and 6 , Table 3 ).

Incidence of $B$. cinerea on flowers and petals. The incidence of $B$. cinerea on flowers from plants treated with $U$. atrum starting at transplanting time was lower than the control in one of two samples in experiment 2; in two of the three samples in experiment 5 ; and in no samples from experiment 3 or 6 (Table 4). There was no significant $(P>0.05)$ difference between the $U$. atrum and the fungicide treatment, except for sample 2, experiment 5 , when the fungicide program resulted in a lower incidence of $B$. cinerea (Table 4 ).

In experiment 7 , the incidence of $B$. cinerea on petals from plots treated with $U$. atrum or fungicides was lower than on those from untreated plots. However, these differences were statistically significant only for sample 1 . The incidence of $B$. cinerea on petals did not differ between the untreated plots and plots with crop sanitation (Table 4).

Fruit quality. Healthy fruit weight, as a measure of quality, did not differ among the treatments except in experiment 5 , in which plants treated twice weekly with $U$. atrum at $2 \times 10^{6}$ conidia/ml from first flowering produced significantly smaller fruit (8.8 $\mathrm{g}$ per fruit) than the untreated control plants (10.3 g per fruit); and in experiment 7 , in which plants sprayed with fungicide produced significantly larger fruit $(13.2 \mathrm{~g})$ than the untreated control plants (11.6 g) (other data not presented).

\section{DISCUSSION}

$U$. atrum was effective in reducing gray mold at harvest in at least one spray program per experiment in four out of seven experiments. In experiments 3 and 7, $U$. atrum failed to show an effect on gray mold, probably due to the low incidence of gray mold (1.4 and $2.2 \%$, respectively). Under the hot, dry weather conditions, 
Table 4. Effect of applications of conidial suspensions of Ulocladium atrum, fungicides, or crop sanitation on the incidence of Botrytis cinerea on strawberry flowers (experiments $2,3,5$, and 6) or petals (experiment 7)

\begin{tabular}{|c|c|c|c|c|c|c|c|c|c|c|}
\hline \multirow[b]{2}{*}{ Experiment $^{\mathrm{w}}$} & \multirow[b]{2}{*}{$\begin{array}{c}\begin{array}{c}\text { Interval } \\
\text { (days) }^{x}\end{array} \\
\end{array}$} & \multicolumn{9}{|c|}{ Incidence of $B$. cinerea on flowers or petals ${ }^{v}$} \\
\hline & & $\begin{array}{c}\text { Untreated } \\
\text { control }\end{array}$ & $\underset{\text { (transplant) }}{U . \text { atrum }}$ & $\begin{array}{c}\text { U. atrum } \\
\text { (flower) }\end{array}$ & $\begin{array}{c}\text { U. atrum } \\
\text { (2-day) }\end{array}$ & $\begin{array}{c}\text { U. atrum } \\
\text { (4-day) }\end{array}$ & $\begin{array}{l}\text { Fungic. } \\
\text { (flower) }\end{array}$ & $\begin{array}{l}\text { Fungic. } \\
\text { (4-day) }\end{array}$ & $\begin{array}{c}\text { Tween } \\
80\end{array}$ & $\begin{array}{c}\text { Crop } \\
\text { sanitation }^{y}\end{array}$ \\
\hline \multicolumn{11}{|l|}{ Experiment 2 (1997) } \\
\hline Sample 1 (10 June) & 5 & $5.1 \mathrm{a}$ & $3.0 \mathrm{a}$ & $3.0 \mathrm{a}$ & $\ldots$ & $\ldots$ & $10.0 \mathrm{a}$ & $\ldots$ & $\ldots$ & $\ldots$ \\
\hline Sample 2 (16 June) & 3 & $14.9 \mathrm{a}$ & $1.3 \mathrm{~b}$ & $1.3 \mathrm{~b}$ & $\ldots$ & $\ldots$ & $6.0 \mathrm{ab}$ & $\ldots$ & $\ldots$ & $\ldots$ \\
\hline \multicolumn{11}{|l|}{ Experiment 3 (1997) } \\
\hline Sample 1 (29 July) & 7 & $76.2 \mathrm{a}$ & $87.0 \mathrm{a}$ & $93.8 \mathrm{a}$ & $\ldots$ & $\ldots$ & $83.0 \mathrm{a}$ & $\ldots$ & $\ldots$ & $\ldots$ \\
\hline Sample 2 (4 August) & 6 & $96.0 \mathrm{a}$ & $92.0 \mathrm{a}$ & $90.0 \mathrm{a}$ & $\ldots$ & $\ldots$ & $97.0 \mathrm{a}$ & $\ldots$ & $\ldots$ & $\ldots$ \\
\hline \multicolumn{11}{|l|}{ Experiment 5 (1998) } \\
\hline Sample 1 (8 June) & $3^{\mathrm{z}}$ & $63.7 \mathrm{a}$ & $33.7 \mathrm{~b}$ & $83.7 \mathrm{a}$ & $\ldots$ & $\ldots$ & $62.5 \mathrm{a}$ & $\ldots$ & $\ldots$ & $65.0 \mathrm{a}$ \\
\hline Sample 2 (15 June) & 4 & $70.0 \mathrm{a}$ & $42.5 \mathrm{bc}$ & $51.2 \mathrm{~b}$ & $\ldots$ & $\ldots$ & $21.3 \mathrm{c}$ & $\ldots$ & $\ldots$ & $62.5 \mathrm{ab}$ \\
\hline Sample 3 (3 July) & 3 & $81.3 \mathrm{a}$ & $66.2 \mathrm{ab}$ & $64.0 \mathrm{ab}$ & $\ldots$ & $\ldots$ & $51.8 \mathrm{~b}$ & $\ldots$ & $\ldots$ & $72.5 \mathrm{a}$ \\
\hline \multicolumn{11}{|l|}{ Experiment 6 (1998) } \\
\hline Sample 1 (21 July) & $5^{z}$ & $83.7 \mathrm{a}$ & $72.5 \mathrm{a}$ & $83.7 \mathrm{a}$ & $\ldots$ & $\ldots$ & $81.2 \mathrm{a}$ & $\ldots$ & $\ldots$ & $80.0 \mathrm{a}$ \\
\hline Sample 2 (5 August) & 1 & $75.0 \mathrm{a}$ & $53.7 \mathrm{a}$ & $63.7 \mathrm{a}$ & $\ldots$ & $\ldots$ & $53.7 \mathrm{a}$ & $\ldots$ & $\ldots$ & $67.5 \mathrm{a}$ \\
\hline Sample 3 (11 August) & 4 & $60.1 \mathrm{a}$ & $51.2 \mathrm{a}$ & $53.7 \mathrm{a}$ & $\ldots$ & $\ldots$ & $55.0 \mathrm{a}$ & $\ldots$ & $\ldots$ & $66.2 \mathrm{a}$ \\
\hline \multicolumn{11}{|l|}{ Experiment 7 (1999) } \\
\hline Sample 1 (28 June) & 2 & $45.0 \mathrm{ab}$ & $\ldots$ & $\ldots$ & $33.5 \mathrm{bc}$ & $25.0 \mathrm{c}$ & $\ldots$ & $24.0 \mathrm{c}$ & $50.5 \mathrm{a}$ & $\ldots$ \\
\hline Sample 2 (30 June) & $2,4^{\mathrm{z}}$ & $18.8 \mathrm{a}$ & $\ldots$ & $\ldots$ & $5.0 \mathrm{a}$ & $5.5 \mathrm{a}$ & $\ldots$ & $12.0 \mathrm{a}$ & $17.0 \mathrm{a}$ & $\ldots$ \\
\hline
\end{tabular}

${ }^{\mathrm{v}} U$. atrum was applied weekly from transplanting (transplant) or from beginning of flowering (flower) (experiments 2, 3, 5, and 6) or at 2- or 4-day intervals (experiment 7); fungicides (Fungic.) were applied from beginning of flowering weekly (experiments 2, 3, 5, and 6) or at 4-day intervals (experiment 7); Tween $80=$ water + Tween 80 applied at 2-day intervals (experiment 7). Values in the same row followed by the same letter are not significantly different $(P>0.05)$ based on least significant difference test.

${ }^{w}$ Experiment 2: thiram $(2 \mathrm{~kg} / \mathrm{ha})$, three applications of tolylfluanide $(0.75 \mathrm{~kg} / \mathrm{ha})$ and pyrimethanil $(0.8 \mathrm{liter} / \mathrm{ha})$ in alternation; experiment 3 : thiram $(2$ $\mathrm{kg} / \mathrm{ha})$, tolylfluanide $(0.75 \mathrm{~kg} / \mathrm{ha})$, and pyrimethanil ( 0.8 liter/ha) in alternation; experiment 5 : three applications of tolylfluanide $(0.75 \mathrm{~kg} / \mathrm{ha}) \mathrm{and}$ three applications of iprodione $(0.75 \mathrm{~kg} / \mathrm{ha})$ in alternation; experiment 6 : three applications of tolylfluanide $(0.75 \mathrm{~kg} / \mathrm{ha})$ and two applications of iprodione $(0.75 \mathrm{~kg} / \mathrm{ha})$ in alternation. experiment 7 : three applications of tolylfluanide $(0.75 \mathrm{~kg} / \mathrm{ha})$ and three applications of iprodione $(0.75 \mathrm{~kg} / \mathrm{ha})$ in alternation.

${ }^{x}$ Intervals between the previous spray and sampling day.

${ }^{y}$ Removal of senescent and necrotic leaflets twice per week from transplanting until first fruit turned red.

${ }^{\mathrm{z}}$ In sample 1, experiments 5 and 6, only treatment 2 had been sprayed before this sampling date; in sample 2, experiment 7, only treatment 2 had been sprayed before the 2-day interval and only treatments 3 and 4 had been sprayed before the 4 -day interval.

overhead (experiment 3) or mist (experiment 7) irrigation systems were inadequate to stimulate gray mold incidence in these experiments.

Compared with applications during flowering only, season-long applications of $U$. atrum resulted in improved control of gray mold at harvest in only one out of five experiments. Bhatt and Vaughan (2) studied the biocontrol of gray mold in strawberry by Cladosporium spp. The effect of the antagonist on reduction of fruit rot at harvest was attributed to prevention of establishment of $B$. cinerea on the senescent and dead flower organs of strawberry. The same mechanism may be involved in the interaction between $U$. atrum and $B$. cinerea. In this case, targeting applications to flower parts would be effective to reduce $B$. cinerea infection. Moreover, the small amount of necrotic leaves produced inside annual strawberry crops may mean that the inoculum produced on these tissues does not play an important role in the epidemiology of gray mold in such cropping systems (3). This could explain the limited additional effect of $U$. atrum treatments before flowering, although the antagonist is able to colonize and suppress the sporulation of $B$. cinerea on dead strawberry leaves (J. Köhl, unpublished data). Crop sanitation by removing senescent and necrotic leaf tissue in our system did not reduce Botrytis spp. infection in comparison with the untreated control as it did in similar experiments in on- ion crops (13) and in another perennial strawberry system using raised beds (16).

More frequent applications of $U$. atrum during flowering may result in better control. In strawberry crops, new flowers are produced each day and flower parts start to senesce after 3 to 5 days. The mode of action of $U$. atrum is by substrate competition (10); therefore, the antagonist should reach the site of colonization on the flower parts before or at the same time as the pathogen. This explains the need for frequent applications to reach all flowers at an early stage.

$U$. atrum tested under low disease pressure in the field showed potential to control gray mold by regularly spraying conidia from transplanting or flowering through beginning of fruit ripening. Further studies should evaluate the performance of the antagonist on strawberry crops under conditions more favorable to gray mold development.

\section{ACKNOWLEDGMENTS}

We thank M. R. Holdinga, J. Mekking, and M. van den Bogert for valuable field help; J. de Kraker for suggestions; and N. J. Fokkema and A. H. C. Van Bruggen for critical reading of the manuscript.

\section{LITERATURE CITED}

1. Anderson, J. P. 1924. Botrytis cinerea in Alaska. Phytopathology 14:152-155.

2. Bhatt, D. D., and Vaughan, E. K. 1963. Interrelationships among fungi associated with strawberries in Oregon. Phytopathology 53:217-220.
3. Boff, P., Kastelein, P., de Kraker, J., Gerlagh, M., and Köhl, J. 2001. Epidemiology of grey mould in annual waiting-bed production of strawberry. Eur. J. Plant Pathol. 107:615-624.

4. Braun, P. G., and Sutton, J. C. 1987. Inoculum sources of Botrytis cinerea in fruit rot of strawberries in Ontario. Can. J. Plant Pathol. 9:1-5.

5. Cook, R. J. 1993. Making greater use of introduced microorganisms for biological control of plant pathogens. Annu. Rev. Phytopathol. 31:53-80.

6. Fruit, L., and Nicot, P. 1999. Biological control of Botrytis cinerea on tomato stem wounds with Ulocladium atrum. IOBC Bull. 22:81-84

7. Jarvis, W. R. 1962. The infection of strawberry and raspberry fruits by Botrytis cinerea Fr. Ann. Appl. Biol. 50:569-575.

8. Jordan, V. W. L. 1978. Epidemiologie und Bekämpfung des Grauschimmels (Botrytis cinerea) an Erdbeeren. Pflanzenschutz-Nachr. 31:1-10.

9. Jordan, V. W. L., and Pappas, A. C. 1977. Inoculum suppression and control of strawberry Botrytis. Proc. Br. Crop Prot. Conf. Pest Dis. 341-348.

10. Kessel, G. J. T. 1999. Biological control of Botrytis spp. by Ulocladium atrum; an ecological analysis. Ph.D. thesis, Wageningen UR, Wageningen, The Netherlands.

11. Köhl, J., Gerlagh, M., de Haas, B. H., and Krijger, M. C. 1998. Biological control of Botrytis cinerea in cyclamen with Ulocladium atrum and Gliocladium roseum under commercial growing conditions. Phytopathology 88:568-575.

12. Köhl, J., Molhoek, W. M. L., van der Plas, C. H., and Fokkema, N. J. 1995. Effect of Ulocladium atrum and other antagonists on sporulation of Botrytis cinerea on dead lily leaves exposed to field conditions. Phyto- 
pathology 85:393-401.

13. Köhl, J., Molhoek, W. M. L., van der Plas, C. H., and Fokkema, N. J. 1995. Suppression of sporulation of Botrytis spp. as a valid biocontrol strategy. Eur. J. Plant Pathol. 101:251259.

14. Lima, G., Ippolito, A., Nigro, F., and Salerno, M. 1997. Effectiveness of Aureobasidium pullulans and Candida oleophila against postharvest strawberry rots. Postharvest Biol. Technol. 10:169-178.

15. Maas, J. L. 1984. Compendium of Strawberry
Diseases. American Phytopathological Society, St. Paul, MN.

16. Mertely, J. C., Chandler, C. K., Xiao, C. L., and Legard, D. E. 2000. Comparison of sanitation and fungicides for management of Botrytis fruit rot of strawberry. Plant Dis. 84:1197-1202.

17. Peng, G., and Sutton, J. C. 1991. Evaluation of microorganisms for biocontrol of Botrytis cinerea in strawberry. Can. J. Plant Pathol. 13:247-257.

18. Rosati, P. 1991. The strawberry in Europe.
Pages $27-35$ in: The strawberry into the $21 \mathrm{st}$ century. A. Dale and J. J. Luby, eds. Proc. Third North Am. Strawberry Conf. Houston. Timber Press, Portland, OR.

19. Schoene, P., and Köhl, J. 1999. Biologische Bekämpfung von Botrytis cinerea mit Ulocladium atrum in Reben and Cyclamen. Gesunde Pflanz. 51:81-85.

20. Sutton, J. C. 1990. Epidemiology and management of Botrytis leaf blight of onion and gray mold of strawberry: a comparative analysis. Can. J. Plant Pathol. 12:100-110. 